\title{
Chronological and physiological ageing in a polar and a temperate mud clam
}

\author{
Eva Philipp, Thomas Brey, Hans-Otto Pörtner, Doris Abele \\ Alfred-Wegener-Institut fiir Polar-und Meeresforschung, Ökophysiologie, Posffach 120161, D-27568 Bremerhaven, Germany,
}

Received 8 October 2004; received in revised form 3 December 2004; accepted 15 December 2004

Available online 22 January 2005

\begin{abstract}
We investigated chronological and physiological ageing of two mud clams with regard to the "rate of living theory" (Pearl, 1928) and the "free radical theory of ageing" (Harman, 1956). The Antarctic Latemula elliptica (Pholadomyoida) and the temperate Mya arenaria (Myoida) represent the same ecotype (benthic infaunal filter feeders), but differ in maximum life span, 36 and 13 years, respectively. $L$. elliptica has a two-fold lower standard metabolic rate than $M$. arenaria, but its life long energy turnover at maximal age is three times higher. When comparing the two species within the lifetime window of $M$. arenaria, antioxidant capacities (glutathione, catalase) are higher and tissue oxidation (ratio of oxidised to reduced glutathione, lipofuscin accumulation) is lower in the polar $L$. elliptica than in the temperate mud clam. Tissue redox state in L. elliptica remained stable throughout all ages, whereas it increased dramatically in aged $M$. arenaria. Our results indicate that metabolic rates and maintenance of tissue redox state are major factors determining maximum lifespan in the investigated mud clams.
\end{abstract}

(C) 2004 Elsevier Ireland Ltd. All rights reserved.

Keywords: Chronological and physiological ageing; Bivalves; ROS

\section{Introduction}

In air breathing species, standard metabolic rate (SMR) seems to be a major factor determining maximum life span (MLSP) (Pearl, 1928; Sohal, 1986). According to the "free radical theory of ageing" (Harman, 1956) this is due to the generation of more reactive oxygen species at higher respiration rate, which damage important cell structures like DNA, protein and lipids, thus leading to a faster deterioration of physiological functions and therefore to a reduction of MLSP.

This relationship was intensively investigated in mammals (rodents, humans) and in short-lived air-breathing invertebrates (Drosophila melanogaster, Caenorhabditis elegans), but to a lesser extent in aquatic ectothermal invertebrates (Hydra, Mytilus edulis, Margaritifera margaritifera, Sepia officinalis) (Viarengo et al., 1989; Canesi and

\footnotetext{
* Corresponding author. Tel.: +494714831 1567; fax: +4947148311149 .

E-mail address: dabele@awi-bremerhaven.de (D. Abele).
}

Viarengo, 1997; Martinez, 1998; Zielinski and Pörtner, 2000; Ziuganov et al., 2000; Sukhotin and Pörtner, 2001; Sukhotin et al., 2002). There is sound empirical evidence for an increase in MLSP of aquatic ectotherms from temperate towards permanently cold waters when comparing species of similar lifestyle (Brey, 1991; Brey et al., 1995; Ziuganov et al., 2000; Cailliet et al., 2001; La Mesa and Vacchi, 2001). This extension of the chronological life span in ectotherms living at permanent cold temperatures requires a delay in physiological ageing. Here, both the "rate of living theory" (Pearl, 1928; Sohal, 1986) and the "free radical theory of ageing" (Harman, 1956) present a convincing yet unconfirmed explanation: at lower temperatures, the lower metabolic rates and correspondingly lower reactive oxygen species propagation from aerobic mitochondrial activity result in a slower rate of physiological ageing. Hence, temperature affects the relationship between chronological age (i.e. absolute life time) and physiological age (i.e. a less clearly defined measure of physiological fitness), which are positively correlated, but not necessarily linearly and in the same way in each species. 
In this study, we compare chronological and physiological ageing of two mud clams, the Antarctic Latemula elliptica (Pholadomyoida) and the North Sea Mya arenaria (Myoida), in order to understand why the polar clam reaches three times the maximum chronological age of the temperate species ( \pm 36 year versus \pm 13 year). MLSP of $M$. arenaria is estimated to be $10-12$ years on the Atlantic east coast (Strasser, 1999), which is in line with the MLSP of 13 years found in our samples. The MLSP of L. elliptica is based on over 650 individual age determinations (this study and $T$. Brey, personal communication) with only two animals reaching 36 years. Both species are of the same ecotype (deep burrowing filter feeding clams) and represent important key species in their respective habitat, but are evolutionary adapted to different temperature regimes. Antarctic waters are characterized by year round stable low temperatures between -1.9 and $+2{ }^{\circ} \mathrm{C}$ (Clarke, 1991). In contrast, species from temperate coastal waters can experience pronounced temperature fluctuations between 0 and $18{ }^{\circ} \mathrm{C}$ and even higher. Most Antarctic marine ectotherms are well adapted to these particular polar conditions, showing a narrow window of thermal tolerance as compared to temperate relatives. Regarding individual growth, reproduction and metabolism, they live their life in the slow lane (Clarke, 1983; Clarke, 1988).

Although L. elliptica and M. arenaria belong to different bivalve subclasses, the similarity in lifestyle in different environments appears just as crucial for such comparisons as a close phylogenetic relationship. Moreover, longer MLSPs in Antarctic animals have also been reported in a comparison of more closely related species, Adamussium colbecki and Aequipecten opercularis (Heilmayer et al., 2003b; Heilmayer et al., 2004). $M$. arenaria is known from America since the Pliocene. In Europe, it became extinct at the beginning of the Pleistocene and is thought to have been reintroduced either in the 13 th or in the 16 th or 17 th century (Petersen et al., 1992). L. elliptica has a continuous history in Antarctic waters, with late Pliocene records from the Northern Antarctic Peninsula (Soot-Ryen, 1952; Jonkers, 1999).

We analysed changes of oxidative stress levels with age and their potential impact on physiological functions in the two mud clam species based on three types of physiological ageing parameters: (i) basic metabolic parameters (standard metabolic rate, tissue protein content), (ii) oxidative defence parameters (superoxide dismutase, catalase, glutathione) and (iii) markers for oxidative damage (lipofuscin, proteincarbonyls).

\section{Material and methods}

\subsection{Sampling and maintenance}

\subsubsection{L. elliptica}

Antarctic L. elliptica were collected by scuba divers in Potter Cove, King George Island, South Shetland Islands $\left(62^{\circ} 14^{\prime} \mathrm{S}, 58^{\circ} 40^{\prime} \mathrm{W}\right)$ in November-February $2002 / 2003$ in $5-$ $10 \mathrm{~m}$ water depth. Temperature and salinity at $10 \mathrm{~m}$ were about -1 to $+2{ }^{\circ} \mathrm{C}$ and 34 PSU. Animals were kept in aquaria with natural seawater from the cove at $0{ }^{\circ} \mathrm{C}$ in a constant temperature room (CT room) at the Argentinean base Jubany (Dallmann-Laboratory) for several days prior to experiments and analyses. Water was exchanged once a week. Measurements of metabolic rate and enzymes activities as well as lipofuscin measurements were carried out at the Dallmann-Laboratory. For all other analyses, samples were freeze-clamped immediately after sacrificing of the animals and stored in liquid nitrogen for deep frozen transportation to the Alfred Wegener Institute, Bremerhaven.

\subsubsection{M. arenaria}

North Sea $M$. arenaria were sampled with a box corer at a shallow subtidal muddy site close to Harlingen $\left(53^{\circ} 09^{\prime} \mathrm{N}\right.$, $05^{\circ} 19^{\prime} \mathrm{E}$ ), The Netherlands. Animals were gently cleaned from sediment and maintained in thermoboxes with natural seawater during transportation to Bremerhaven. At the Alfred Wegener Institute, animals were transferred to seawater $\left(10^{\circ} \mathrm{C}, 28 \mathrm{PSU}\right)$ aquaria with a $20 \mathrm{~cm}$ sediment layer. On contact with the sediment the animals immediately started burrowing. Animals were fed plankton tablets (REWE, Germany) twice a week, and individuals carried plankton material in the stomach when dissected.

\subsection{Age detemination}

Age of individual $M$. arenaria was inferred from shell length and a Von Bertalanffy growth model (VBGM) based on length-at-age data of the same subtidal population:

$$
\begin{aligned}
& S_{t}=117.17\left(1-e^{-0.12(t+0.054)}\right), \\
& \quad N=181 \text { data points from } 23 \text { animals. }
\end{aligned}
$$

The length at-age-data were obtained by isotope analysis (Krantz et al., 1984; Wefer and Berger, 1991) and the investigation of shell growth bands (MacDonald and Thomas, 1980; Brousseau and Baglivo, 1987) of $M$. arenaria individuals. For isotope analysis, calcium carbonate powder was sampled from the outer shell layer of four individuals in equally spaced $(\sim 1 \mathrm{~mm})$ dorso-ventral series using a small dental drill (bit size $0.5 \mathrm{~mm}$ ). $\delta^{13} \mathrm{C}$ and $\delta^{18} \mathrm{O}$ values were determined in the Stable Isotope Laboratory of the Institute of Palaeontology of the University of Munich with a coupled analysing system Gasbench II/Delta plus (Thermo Finnigan). Isotope profiles $\left({ }^{13} \mathrm{C} /{ }^{12} \mathrm{C}\right)$ and $\left({ }^{18} \mathrm{O} /{ }^{16} \mathrm{O}\right)$ were compared with corresponding growth checks visible on the outer shell surface and in X-ray photographs, to distinguish between age rings and disturbance rings as described in Heilmayer et al. (2003b, 2004). In these four $M$. arenaria individuals and 19 additional shells, where growth bands were clearly visible on the outer shell and X-ray, the distance of identified year rings to the umbo was then 


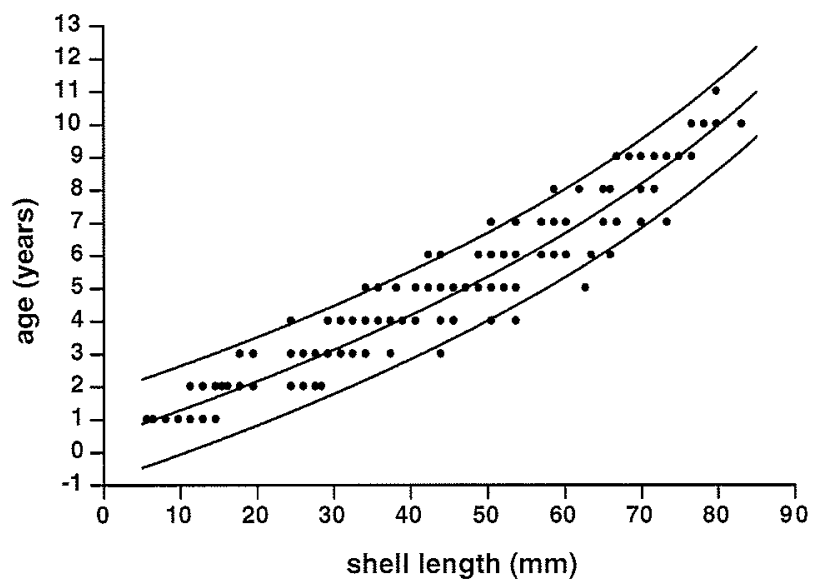

Fig. 1. Inverse Von Bertallanffy growth model (VBGM) of $M$. arenaria with the upper and lower $95 \%$ confidence limits, inferred from 181 size-atage data points ( 23 individuals, age range $=1-10$ years)

determined resulting in 181 width-to-age data points, which were transformed to length-to-age data points by a widthlength conversion factor of 0.617 inferred from $259 \mathrm{M}$. arenaria shells. A length-to-age curve was then fitted using a Von Bertalanffy growth model (VBGM) (Fig. 1).

In contrast to $M$. arenaria, the relation between shell length and age was found to be more variable in L. elliptica. Hence, every individual was aged directly by counting the annually formed growth checks (Brey and Mackensen, 1997) in polished cuts through the shell umbo. A few damaged shells could not be aged as previously described. For these individuals age was inferred from a length-at-age table (age " $y$ " found at shell length " $x$ "), based on the 347 directly aged shells.

\subsection{Metabolic rate}

Prior to respiration measurements, $M$. arenaria and $L$. elliptica were maintained without food for 2 and 3 days, respectively, in order to eliminate impact of specific dynamic action (SDA) on respiration.

Standard metabolism was approximated by standard respiration measured in a multi-channel modified intermittent flow system and oxygen microoptodes connected to a Microx TX 2-array (PreSens ${ }^{\circledR} \mathrm{GmbH}$ ), as previously described in Gatti et al. (2002) and Heilmayer and Brey (2003a). The respiration chambers were perspex cylinders of different volumes, adjustable to the size of the animals (150$990 \mathrm{ml}$ ). Experimental conditions were maintained at $10^{\circ} \mathrm{C}$ and $27 \mathrm{PSU}$ in $M$. arenaria, and at $0 \pm 0.4^{\circ} \mathrm{C}$ and $34 \mathrm{PSU}$ in L. elliptica. Microoptodes were calibrated to $100 \%$ oxygen solubility in air-saturated and to $0 \%$ in $\mathrm{N}_{2}$-saturated seawater at both experimental temperatures.

Bivalves were allowed to accommodate to the respiration chambers overnight. Only actively respiring animals that had their siphons extended into the surrounding water were measured. A measurement cycle was initiated by switching the system from "flow-through" to "closed-circle flow" status, starting the first measurement run. The water in the closed system was continuously circulated by a peristaltic pump (Spetec Perimax 127) and the decrease in oxygen content from $100 \%$ to about $70 \%$ oxygen over time was recorded. At about $70 \%$ oxygen, the system was switched back to "flow-through" and flushed with water to achieve $100 \%$ oxygen saturation, then a new run started. Two to three runs, taking about $4-5 \mathrm{~h}$ each, were carried out per animal. Immediately upon completion of the measurement cycle, the animal was dissected and soft tissue wet mass was determined. The soft tissue was dried at $60^{\circ} \mathrm{C}$ for at least 3 days to determine dry mass. Tissues were combusted at $500^{\circ} \mathrm{C}$ for $5 \mathrm{~h}$ (Ahn and Shim, 1998) and ash mass was subtracted from dry mass to obtain ash free dry mass. Standard metabolic rates (SMR) were determined after subtraction of the microbial oxygen demand, determined in a parallel blank chamber. Percent $\mathrm{O}_{2}$ saturation was transformed to micromoles of dissolved oxygen in seawater using known values of oxygen solubility (Benson and Krause, 1984; Heilmayer and Brey, 2003a) and converted to microgram $\mathrm{O}_{2}$ by $1 \mu \mathrm{mol} \mathrm{O} \mathrm{O}_{2}=32.32 \mu \mathrm{g} \mathrm{O}$.

Life-long aerobic expenses were approximated using lifetime respiration, i.e. total aerobic energy gain $L R_{t}$ of an individual until age $t$. A model to estimate $\mathrm{LR}_{t}$ was build from the following components:

The Von Bertalanffy growth model (Von Bertalanffy, 1934) describes the relation between body size $S_{t}$ and individual age $t$ :

$S_{t}=S_{\infty}\left(1-\mathrm{e}^{-K\left(t-t_{o}\right)}\right)$

where $S_{\infty}$ is asymptotic maximal size, $K$ the acceleration constant, $t$ age, and $t_{\mathrm{o}}$ age at which length would be zero. With the exponential body size to body mass relation:

$M_{t}=a 1 \times S_{t}^{b 1}$

growth in size is transformed into growth in body mass:

$M_{t}=a 1 \times S_{\infty}^{b 1}\left(1-\mathrm{e}^{-K\left(t-t_{o}\right)}\right)^{b 1}$
$\Leftrightarrow M_{t}=M_{\infty}\left(1-\mathrm{e}^{-K\left(t-t_{o}\right)}\right)^{b 1}$

where $M_{\infty}$ is asymptotic body mass. Standard respiration $R_{t}$ is related to body mass $M_{t}$ by the exponential relation

$R_{t}=a 2 \times M_{t}^{b 2}$

and hence to age $t$ by

$$
\begin{aligned}
& R_{t}=a 2\left(M_{\infty}\left(1-\mathrm{e}^{-K\left(t-t_{o}\right)}\right)^{b 1}\right)^{b 2} \\
& \Leftrightarrow R_{t}=a 2\left(a 1 \times S_{\infty}^{b 1}\left(1-\mathrm{e}^{-K\left(t-t_{o}\right)}\right)^{b 1}\right)^{b 2}
\end{aligned}
$$

Lifetime respiration $\mathrm{LR}_{t}$ is computed by numerical integration, i.e. by accumulating respiration computed for subsequent small time intervals $\mathrm{d} t$ from age zero to age $t$ :

$\mathrm{LR}_{t}=\sum R_{t} \mathrm{~d} t$

Additional respiration data for $L$. elliptica obtained by Ahn and Shim (1998) were included in the analysis. The specific parameters used for calculating lifetime respiration are shown in Table 1. 
Table 1

Equations used for lifetime respiration model of $M$. arenaria and $L$. elliptica

\begin{tabular}{lll}
\hline & $M$, arenaria & L. elliptica \\
\hline $\begin{array}{l}\text { Growth }(\mathrm{VBGM}) \\
\quad[\mathrm{mm}, \text { years] }\end{array}$ & $S_{t}=117.17\left(1-\mathrm{e}^{-0.12(t+0.054)}\right), N=181, r^{2}=0.934$ & $S_{t}=101.39\left(1-\mathrm{e}^{-0.060(t+0.00)}\right), N=347, r^{2}=0.806$ \\
$\begin{array}{c}\text { Size-mass [mm, } \\
\quad \text { mg AFDM] }\end{array}$ & $\log M=3.029 \times \log S-2.623, N=90, r^{2}=0.898, P<0.001$ & $\log M=3.074 \times \log S-2.531, N=28, r^{2}=0.947, P<0.001$ \\
$\begin{array}{c}\text { Respiration-mass } \\
{[\mathrm{J} / \mathrm{d}, \mathrm{J}]}\end{array}$ & $\log R=0.86 \times \log M-1.833, N=19, r^{2}=0.70, P<0.001$ & ${ }^{\mathrm{a}} \log R=0.888 \times \log M-2.067, N=74, r^{2}=0.777, P<0.001$ \\
\end{tabular}

${ }^{a}$ Respiration data from the present study and Ahn and Shim (1998).

\subsection{Enzyme assays}

For enzyme assays, animals were dissected and mantle tissue freeze-clamped and stored in liquid nitrogen. Assay temperature was $0^{\circ} \mathrm{C}$ for L. elliptica, $10^{\circ} \mathrm{C}$ for $M$. arenaria, and $20^{\circ} \mathrm{C}$ for reference. All assays were measured spectrophotometrically (Pharmacia, Shimatzu UV 1202 for L. elliptica and Beckman DU 7400i for M. arenaria). Data are expressed as international units ( $\mu \mathrm{mol}$ of substrate converted to product $\min ^{-1}$ ) per mg protein. Protein content of the extracts was determined by the Biuret method (Kresze, 1988).

\subsubsection{Superoxide dismutase}

Superoxide dismutase (SOD) was determined after Livingstone et al. (1992). Frozen mantle tissue was ground in liquid nitrogen and homogenised with a micropistill in Tris buffer (20 mM Tris-HCl, $1 \mathrm{mM}$ EDTA, pH 7.6) 1:8 (w/ v). Samples were centrifuged for $3 \mathrm{~min}$ at $14,000 \mathrm{rpm}$ and at $2{ }^{\circ} \mathrm{C}$. SOD activity was measured as degree of inhibition of the reduction of cytochrome $\mathrm{c}$ by superoxides generated by a xanthine oxidase/xanthine system at $550 \mathrm{~nm}$ in $43 \mathrm{mM}$ potassium buffer with $0.1 \mathrm{mM}$ EDTA, $\mathrm{pH} 7.8$. One unit SOD causes a $50 \%$ inhibition under the assay conditions.

\subsubsection{Catalase}

Catalase activity was determined after Aebi (1984). Frozen mantle tissue was ground in liquid nitrogen and homogenised with a micropistill in $50 \mathrm{mM}$ phosphate buffer (50 $\mathrm{mM} \mathrm{KH}_{2} \mathrm{PO}_{4}, 50 \mathrm{mM} \mathrm{Na} \mathrm{HPO}_{4}, \mathrm{pH} \mathrm{7.0)}$ with $0.1 \%$ Triton $\mathrm{x}-100$ at $1: 5(\mathrm{w} / \mathrm{v})$. Samples were centrifuged at $13,000 \times g$ for $15 \mathrm{~min}$ at $2{ }^{\circ} \mathrm{C}$. The activity was determined by recording the time of $\mathrm{H}_{2} \mathrm{O}_{2}$ decomposition, resulting in a decrease of absorption from 0.45 to 0.4 at $240 \mathrm{~nm}$ ( 1 unit).

\subsection{Glutathione content}

The concentrations of the oxidised (GSSG) and the reduced form of glutathione (GSH) were measured after Fariss and Reed (1987) using high performance liquid chromatography (HPLC). The principle of the measurement is the derivatisation of the thiols with dinitrofluobenzene (DNFB). GSH oxidation during extraction is prevented by iodoacetic acid (IAA) binding of GSH. Immediately after dissecting an animal, the tissue was freeze-clamped to prevent GSH oxidation and kept in liquid nitrogen. Tissues were ground in liquid nitrogen and homogenised with ice-cold perchloric acid (PCA) (10\% with $2 \mathrm{mM}$ bathophenanthrolinedisulfonic acid) at $1 / 10(\mathrm{w} / \mathrm{v})$. Following centrifugation at $15,000 \times g$ and $4{ }^{\circ} \mathrm{C}$ for $5 \mathrm{~min}, 500 \mu \mathrm{l}$ of the supernatant was transferred to a fresh reaction vial and $10 \mu \mathrm{l}$ of the $\mathrm{pH}$ indicator ( $1 \mathrm{mM} m$-cresol purple in $\mathrm{H}_{2} \mathrm{O}$ with $0.5 \mathrm{M}$ iodoacetic acid) and $50 \mu \mathrm{l}$ internal standard $(1 \mathrm{mM}$ gamma-glutamyl-glutamat in $0.3 \%$ PCA) added. Samples were adjusted to $\mathrm{pH} 8.5$ with $4 \mathrm{M} \mathrm{KOH}$ with $0.3 \mathrm{M} n$ morpholinopropanesulfonic acid and incubated for $45 \mathrm{~min}$ at room temperature, to allow iodoacetic acid to bind the GSH. After 5 min centrifugation at $15,000 \times g$ and $4{ }^{\circ} \mathrm{C}, 1 \% \mathrm{DNFB}$ (1\% 1-fluoro-2.4-dinitrobenzene in ethanol) was added to the supernatant at a 1:3 ratio and incubated in a dark vial for $24 \mathrm{~h}$ at room temperature without shaking. Thereafter, samples could be kept frozen for at least 6 months until analysis. Prior to injection into the HPLC, thawed samples were again centrifuged for $1 \mathrm{~min}$ at $7500 \times g$ and $4{ }^{\circ} \mathrm{C}$, to remove remaining PCA and the supernatant filtered through a $0.2 \mu \mathrm{m}$ nylon membrane filter. Samples were transferred to dark autosampler vials and injected using an autosampler, thermostatted to $4{ }^{\circ} \mathrm{C}$. Separation was achieved on a $\mathrm{NH}_{2}-$ sperisorb column $(240 \mathrm{~mm} \times 4 \mathrm{~mm} \times 5 \mu \mathrm{m}$ particles $)$ at $39^{\circ} \mathrm{C}$ using a binary solvent system of A: $80 \%$ methanol/ water and B: $80 \%$ solvent $A$ and $20 \%$ acetate stock ( $272 \mathrm{~g} \mathrm{Na}$ acetate-trihydrate diluted in $122 \mathrm{ml}$ water plus $378 \mathrm{ml}$ glacial acetic acid). Both solvents were degassed and filtered $\left(0.45 \mu \mathrm{m}\right.$ pore size) prior to use. Flow rate was $1.2 \mathrm{ml} \mathrm{min}{ }^{-1}$ 1 at a maximal backpressure of 2500 psi. The gradient program was: $90 \% \mathrm{~A} / 10 \% \mathrm{~B}$ for $12 \mathrm{~min}$, followed by $30 \mathrm{~min}$ of linear gradient elution to $45 \% \mathrm{~A} / 55 \% \mathrm{~B}$ and a subsequent 8 min hold. Thereafter, the system was returned to the initial conditions within $5 \mathrm{~min}$ and re-equilibrated for $15 \mathrm{~min}$.

\subsection{Proteinoxidation}

Detection of protein carbonyl groups as a measure of protein oxidative modifications was carried out after Levine et al. (1990). Carbonyls react with the carbonyl-specific reagent 2.4-dinitrophenylhydrazine (DNTP) and can be measured spectrophotometrically at $360 \mathrm{~nm}$ (molar extinction coefficient $E=22,000 \mathrm{M}^{-1} \mathrm{~cm}^{-1}$ ).

Samples were homogenised in $5 \mathrm{ml}$ of $50 \mathrm{mM}$ HEPES containing $125 \mathrm{mM} \mathrm{KCl}$ and protease inhibitors $(0.5 \mathrm{mg} / \mathrm{ml}$ 
leupeptine, $0.7 \mu \mathrm{g} / \mathrm{ml}$ pepstatine, $40 \mu \mathrm{g} / \mathrm{ml}$ phenylmethylsulfonyl fluoride, $0.5 \mu \mathrm{g} / \mathrm{ml}$ aprotinine, $1.1 \mathrm{mM}$ EDTA, $0.6 \mathrm{mM} \mathrm{MgSO}_{4}$ ) and centrifuged at $31,000 \times g$ for $15 \mathrm{~min}$. $0.4 \mathrm{ml}$ of supernatants were incubated at room temperature for $1 \mathrm{~h}$ with $1.4 \mathrm{ml} 10 \mathrm{mM}$ DNTP in $2 \mathrm{M} \mathrm{HCl}$. Absorbance blanks of samples were run without DNTP. During the incubation, samples were vortexed every $15 \mathrm{~min}$. After $1 \mathrm{~h}$, $0.2 \mathrm{ml}$ of $100 \%$ TCA were added to precipitate the protein and centrifuged for $10 \mathrm{~min}$ at $11,000 \times \mathrm{g}$. The protein pellet was washed three times with $1 \mathrm{ml}$ ethanol:ethylacetate $(1: 1)$, resuspended in $0.6 \mathrm{ml} 6 \mathrm{M}$ guanidine hydrochloride in $20 \mathrm{mM}$ potassium phosphate $(\mathrm{pH} 2.3)$ and incubated in a water bath for $30 \mathrm{~min}$ at $37^{\circ} \mathrm{C}$ until complete resuspension. Samples were kept in the refrigerator overnight and measured the following day in the photometer (Pharmacia Biochrom 4060) with guanidine hydrochloride as a reference. The protein content of the samples was determined by the Bradford method using bovine serum albumin as a standard.

\subsection{Fluorescent age pigment, lipofuscin}

Lipofuscin contents were determined by an extraction method modified after Vernet et al. (1988). Frozen mantle tissue was ground in liquid nitrogen and homogenised $(1 / 20$ $\mathrm{w} / \mathrm{v})$ in a chloroform-methanol solution $(2: 1 \mathrm{v} / \mathrm{v})$. The homogenate was mixed with $100 \mathrm{mM} \mathrm{MgCl}_{2}$ (1 $\mathrm{ml}$ per each $4 \mathrm{ml}$ of chloroform $/$ methanol) solution. After $15 \mathrm{~min}$ centrifugation at $2000 \times g$, the chloroform phase was collected and mixed with distilled water $(1 \mathrm{ml}$ per $4 \mathrm{ml}$ initial chloroform/methanol). After $20 \mathrm{~min}$ at $2000 \times \mathrm{g}$ and at $0{ }^{\circ} \mathrm{C}$, the chloroform phase was again collected and could be measured in the fluorometer. An emission spectrum was obtained at an excitation wavelength of $350 \mathrm{~nm}$. The fluorescence intensity of each sample was determined at an emission maximum of $415 \mathrm{~nm}$ for L. elliptica and $464 \mathrm{~nm}$ for $M$. arenaria. According to Hill and Womersley (1991), lipofuscin concentrations were expressed as relative fluorescent intensity (RFI) using $0.1 \mu \mathrm{g}$ quinine sulphate per $\mathrm{ml} 1 \mathrm{~N} \mathrm{H}_{2} \mathrm{SO}_{4}$ as standard.

\subsection{Protein content}

Mantle tissue of both species was lyophilised and then reduced to small pieces with a spatula. $3 \% \mathrm{NaOH}$ was added at a 1:50 (w/v) ratio and shaken for $20 \mathrm{~h}$ at room temperature to hydrolyse the protein. Subsequently, samples were centrifuged for $20 \mathrm{~min}$ at $5000 \mathrm{rpm}$ to remove cell debris and cooled on ice to facilitate protein precipitation. A two-fold volume of ice-cold $60 \%$ TCA was added (30 $\mathrm{ml}$ per initial gram tissue dry mass) to precipitate the protein. After $20 \mathrm{~min}$ at $5000 \mathrm{rpm}$, the supernatant was discharged and the pellet dissolved in $3 \%$ $\mathrm{NaOH}$ using $20 \mathrm{ml}$ per initial gram tissue dry mass. Protein concentration was determined spectrophotometrically with the Biuret method.

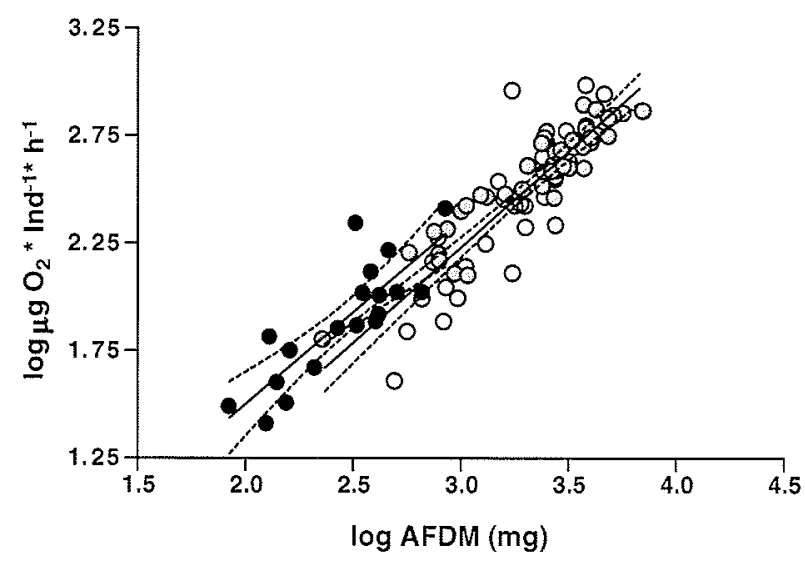

Fig. 2. Respiration rates $\left(\mu \mathrm{g} \mathrm{O}_{2}\right.$ ind $^{-1} \mathrm{~h}^{-1}$ ) of $M$. arenaria (filled circles, $N=19$, mass range $=85-852 \mathrm{mg}$ AFDM) and $L$. elliptica (open circles: this study, $N=28$; grey dots: data from Ahn and Shim (1998), $N=45$, mass range $=85-852 \mathrm{mg}$ AFDM $)$ measured at in situ temperatures $\left(10^{\circ} \mathrm{C} \mathrm{M}\right.$. arenaria, $0^{\circ} \mathrm{C}\left(0.8^{\circ} \mathrm{C}\right.$ Ahn and Shim) L. elliptica $) . M$. arenaria: $\log$ $R=0.86 \times \log (\mathrm{mg}$ AFDM $)-0.214 ; r^{2}=0.70 ; N=19 ;$ L. elliptica (this study and Ahn and Shim, 1998): $\log R=0.888 \times \log (\mathrm{mg}$ AFDM $)-0.436$; $r^{2}=0.777 ; N=74$. Intercepts differed significantly $(P=0.023$, ANCOVA $)$ but slopes did not.

\subsection{Statistical analysis}

Relationships between parameters and age and differences between species were evaluated by analysis of variance (ANOVA) and analysis of covariance (ANCOVA) after testing for normality by the Kolmogorov-Smirnov test.

\section{Results}

\subsection{Whole animal metabolism and tissue protein content}

Whole animal respiration rates, measured at in situ temperature $\left(M\right.$. arenaria $10^{\circ} \mathrm{C}$, L. elliptica $0^{\circ} \mathrm{C}$ ) were about two-fold higher in $M$. arenaria compared to $L$. elliptica (Fig. 2) at the same AFDM. The lifetime aerobic expenses of $M$. arenaria and $L$. elliptica computed from the corresponding models relating body size to age, body mass to body size and respiration rate to body mass are shown in Fig. 3. Life-long aerobic expenses, accumulated at maximum age, are three times higher in L. elliptica $\left(8.98 \times 10^{5} \mathrm{~J}\right.$ ind $^{-1}$ at 36 years of age $)$ than in $M$. arenaria $\left(3.00 \times 10^{5} \mathrm{~J}\right.$ ind $^{-1}$ at 13 years of age $)$.

Measurements of tissue protein content in the mantle tissue revealed an increase in tissue protein content per gram dry mass with age in $L$. elliptica, but not in $M$. arenaria (Fig. 4). In $L$. elliptica, protein concentrations decreased

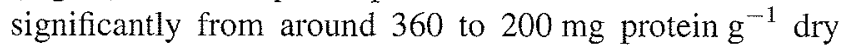
mass between 4 and 36 years of age. In $M$. arenaria, values varied around $450 \mathrm{mg}$ protein $\mathrm{g}^{-1}$ dry mass throughout all age classes. 


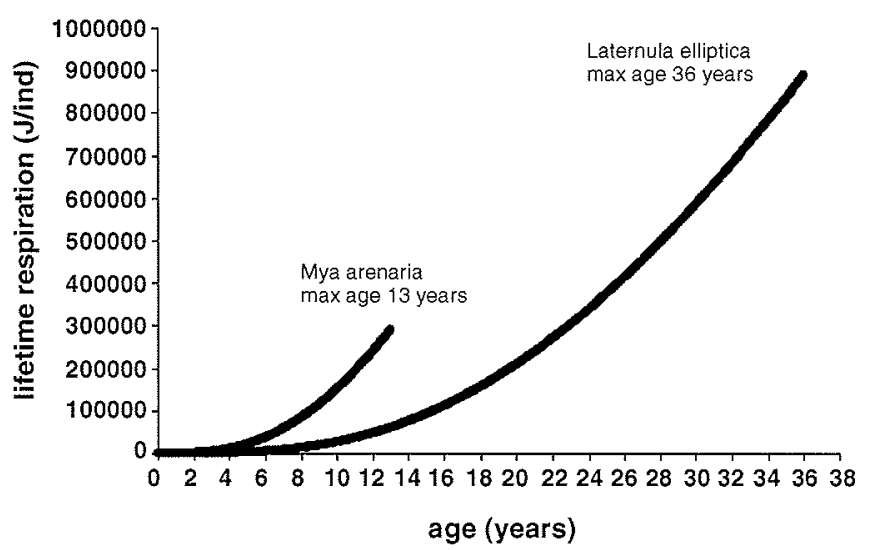

Fig. 3. Lifetime aerobic expenses of $M$. arenaria and L. elliptica were computed from the corresponding models shown in Table 1. AFDM was converted to Joule (J) by a conversion factor of $21,465 \mathrm{~J} / \mathrm{mg}$ AFDM for $M$. arenaria and $20.37 \mathrm{~J} / \mathrm{mg}$ AFDM for $L$. elliptica from compiled data by $\mathrm{T}$. Brey (unpublished).

\subsection{Age dependent changes of antioxidant defence mechanisms}

The activity of the antioxidant enzymes superoxidedismutase (SOD) and catalase (CAT) were constant throughout all ages in both species. A between species comparison yielded similar SOD activities in both animals, independently of whether assays were run at $20^{\circ} \mathrm{C}$ reference temperature or at in situ temperature $\left(10^{\circ} \mathrm{C}\right.$ for $M$. arenaria and $0^{\circ} \mathrm{C}$ for $L$. elliptica) (Fig. 5A). In contrast, catalase (CAT) activities were distinctly higher in L. elliptica than in $M$. arenaria at $20^{\circ} \mathrm{C}$ assay temperature. At in situ temperature $\left(10^{\circ} \mathrm{C}\right)$, catalase activity was below detection limits in $M$. arenaria mantle (Fig. 5B). Q10 values were close to 1 for SOD in both species and were 1.8 for CAT in $L$.

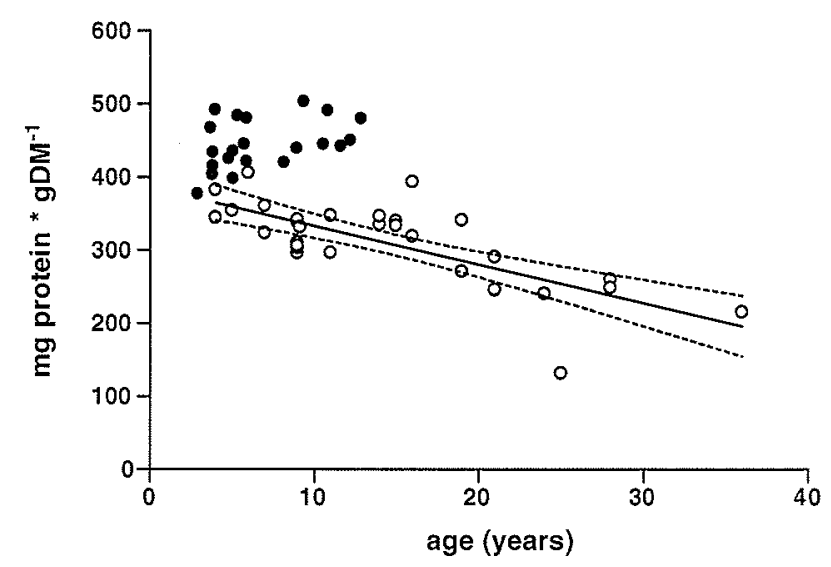

Fig. 4. Protein content (mg protein $\mathrm{g}^{-1}$ dry mass) in mantle tissue of $M$. arenaria (filled circles, $N=22$, age range $=3-13$, mass range $=84$ $3368 \mathrm{mg}$ AFDM) and L. elliptica (open circles, $N=31$, age range $=4-$ 36 , mass range $=433-3062$ ) plotted against chronological age (years). Data represent means of duplicate measurements. Slopes differed significantly between species $(P<0.001$, ANCOVA). L. elliptica: protein content $=-5.27 \times$ age $+386.0, r^{2}=0.55, N=31 ; M$, arenaria: no significant relationship (slope $=0$ ).
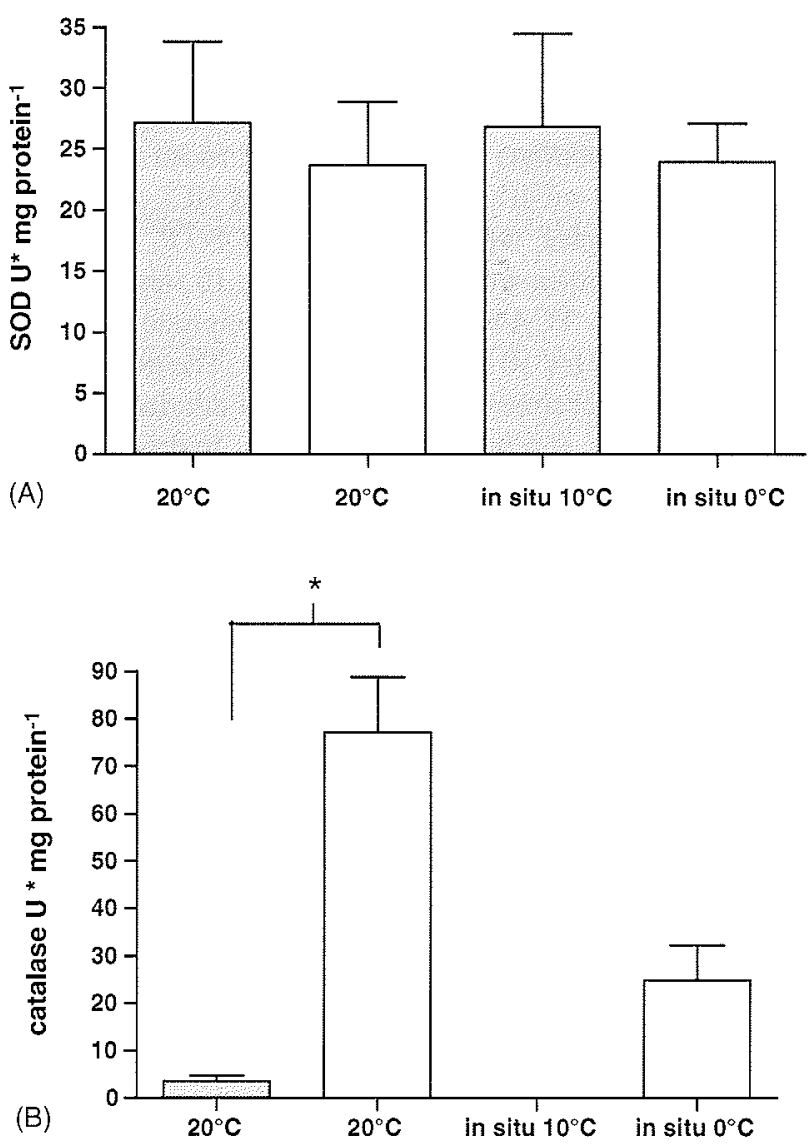

Fig. 5. Activities of superoxide-dismutase (A) and catalase (B) in mantle tissue of $M$. arenaria (M.a., grey bars) and $L$. elliptica (L.e., white bars) at $20^{\circ} \mathrm{C}$ reference temperature and at in situ temperature for both species, $10^{\circ} \mathrm{C}$ (M.a.) and $0^{\circ} \mathrm{C}$ (L.e.). Data are mean \pm S.D. expressed as $\mathrm{U} \mathrm{mg}^{-1}$ protein as average over all ages. Age of $M$. arenaria ranged between 2 and 8 years (mass range $=47-1187 \mathrm{mg}$ AFDM) and of $L$. elliptica $2-28$ years (mass range $=95-3278 \mathrm{mg}$ AFDM) (2-36 years for L.e. SOD, mass range $=122-3278 \mathrm{mg}$ AFDM). (*) Significant difference with $P<0.001$ (Student's $t$-test). $N$ catalase, (SOD) $=16$ (17) (M.a.) and 29 (38-44) (L.e.).

elliptica. Due to the low CAT activity at $10^{\circ} \mathrm{C}, \mathrm{Q} 10$ for CAT of $M$. arenaria could not be calculated.

Throughout the lifetime of $M$. arenaria, the concentration of total tissue glutathione (tGSH: $2[\mathrm{GSSG}]+[\mathrm{GSH}]$ ) was higher in L. elliptica than M. arenaria, (Fig. 6A). Old $L$. elliptica specimens ( $>15$ years) showed tGSH values in the same range as old $M$. arenaria. tGSH concentrations in L. elliptica declined significantly with age (Fig. 6A) from approximately 850 to $380 \mathrm{nmol}$ tGSH $\mathrm{g}^{-1}$ wet mass, whereas in $M$. arenaria mantle tissue tGSH values increased significantly with age from approximately 200 to $420 \mathrm{nmol} \mathrm{tGSH} \mathrm{g^{-1 }}$ wet mass (Fig. 6A). Mantle tissue of $M$. arenaria was more oxidized (ratio GSSG:GSSG) than L. elliptica throughout all ages, and tissue oxidation increased significantly with age in $M$. arenaria, due to an increase in GSSG (Fig. 6B), whereas in L. elliptica age-dependent tissue oxidation remained constant (Fig. 6C). 

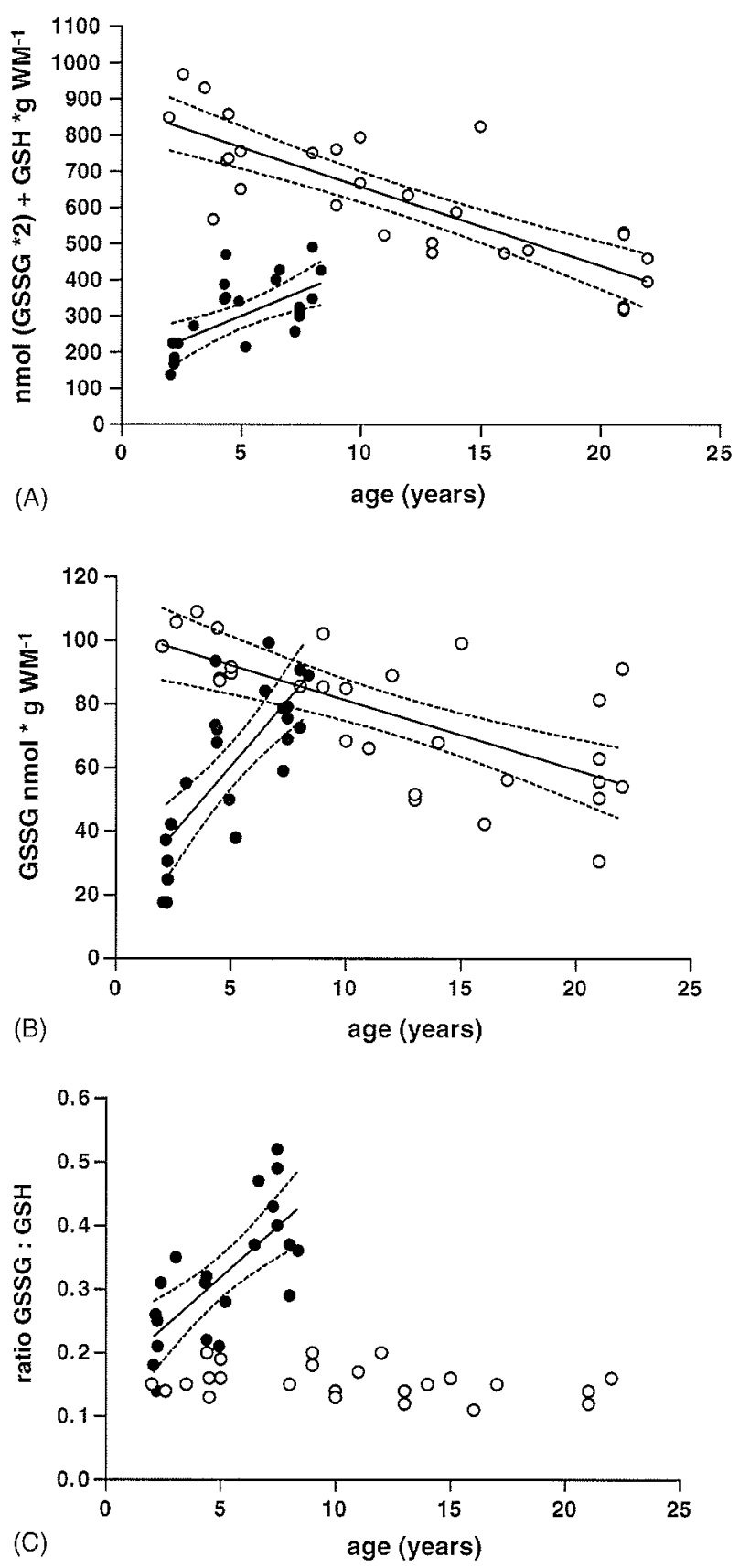

Fig. 6. Concentration of (A) total ( $\mathrm{tGSH}=2 \times \mathrm{GSSG}+\mathrm{GSH})$, (B) oxidised glutathione (GSSG), and (C) the ratio of oxidised to reduced glutathione (GSSG/GSH) in mantle tissue of $M$. arenaria (filled circles, $N=23$, for ratio $N=21$; age range $=2-8$ years, mass range $=42-$ $1187 \mathrm{mg}$ AFDM) and L. elliptica (open circles, tGSH $N=29$, GSSG $N=28$, for ratio $N=25$; age range $=2-22$ years; mass range $=100$ $2563 \mathrm{mg}$ AFDM) vs. chronological age. Data represent means of duplicate measurements of $1-4$ pooled animals. Slopes differed significantly between species $(P<0.001$, ANCOVA). tGSH: $M$. arenaria: $\mathrm{tGSH}=27.67 \times$ age $+171.4, r^{2}=0.38, N=23, P=0.0017 ;$ L. elliptica: $\mathrm{tGSH}=-21.71 \times$ age $+874.2, r^{2}=0.66, N=29, P<0.0016$. GSSG: $M$. arenaria: $\mathrm{GSSG}=8.57 \times$ age $+20.73, r^{2}=0.599, N=23, P<0.001, L$. elliptica: $\mathrm{GSSG}=-2.190 \times$ age $+103.2, r^{2}=0.47, N=28, P<0.001$. GSSG:GSH: $M$. arenaria: GSSG:GSH $=0.0324 \times$ age $+0.168, r^{2}=$ $0.52, N=21, \quad P<0.001 ; \quad L$. elliptica: no significant relationship (slope $=0$ ).

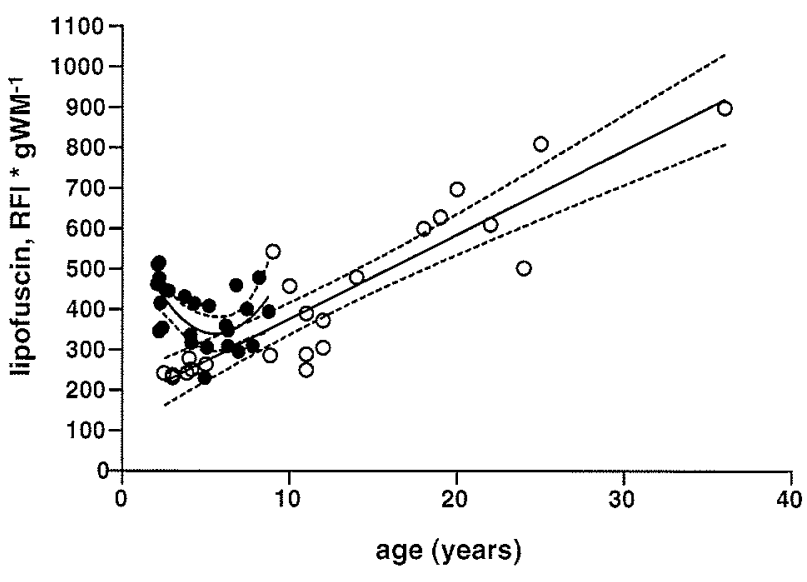

Fig. 7. Lipofuscin content (relative fluorescence intensity (RFI) $\mathrm{g}^{-1}$ wett mass) vs. chronological age (years) in mantle tissue of $M$. arenaria (filled circles, $N=24$, age range $=2-8$ years, mass range $=42-1187 \mathrm{mg}$ AFDM) and $L$. elliptica (open circles, $N=23$, age range $=2.5-36$ years, mass range $=135-3279 \mathrm{mg}$ AFDM). L. elliptica: lipofuscin $=20.88 \times$ age $+167.5 ; r^{2}=0.82 ; N=23, P<0.05$. The relation between lipofuscin and age for $M$. arenaria was descibed best by the polynome: lipofus$\operatorname{cin}=592.9+(-97.83) \times$ age $+9.383 \times$ age $^{2}, r^{2}=0.334, N=24, P$ function $=0.0127, P$ intercept $<0.001, P$ slope $1=0.0226, P$ slope $2=0.0126$.

\subsection{Age-dependent changes in oxidative damage parameters}

The deposition of both lipofuscin and protein carbonyls in mantle tissue of L. elliptica (Figs. 7 and 8) increased significantly with age. In contrast to the findings in $L$. elliptica, the carbonyl content decreased with age in $M$. arenaria (Fig. 8). Lipofuscin contents also decreased during the first 5 years of life but increased thereafter (Fig. 7). Within the lifetime window of $M$. arenaria lipofuscin content was generally higher in $M$. arenaria compared to $L$. elliptica. Protein carbonyl contents were in the same range in young specimens from both species. Given the pronounced increase in protein carbonyl content with age in L. elliptica as opposed to the age dependent decline in $M$. arenaria, protein carbonyl content was higher in aged $L$. elliptica mantle tissue, compared to aged $M$. arenaria.

\section{Discussion}

\subsection{Does MLSP rely more on standard metabolic rate or more on lifetime respiration?}

The species with the distinctly shorter life span, $M$. arenaria, shows a two-fold higher standard metabolic rate (SMR) at in situ temperature (Fig. 2), but three times lower life-long aerobic expenses (Fig. 3) than the longer-lived $L$. elliptica.

This indicates that MLSP relates more to the instantaneous rate of respiration than to cumulative lifetime respiration. Our findings coincide with those obtained in a study of two rodent species with different MLSP, where the 


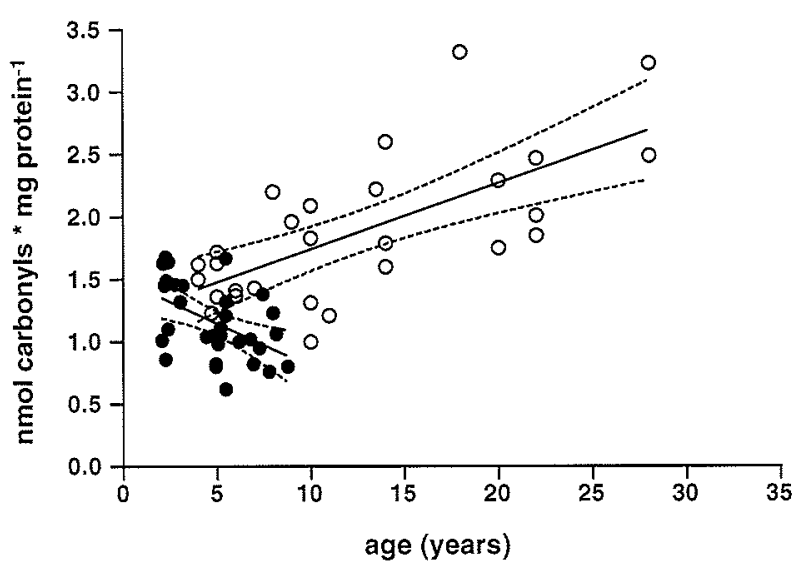

Fig. 8. Protein carbonyl content (nmol $\mathrm{mg}^{-1}$ protein) in mantle tissue of $M$. arenaria (filled circles, $N=31$, age range $=2-8$ years, mass range $=42$ $1187 \mathrm{mg}$ AFDM) and $L$. elliptica (open circles, $N=28$, age range $=4-28$, mass range $=227-3506 \mathrm{mg} A F D M$ ) vs. chronological age (years) Each data point refers to one individual. Slopes differed significantly between species $(P<0.001$, ANCOVA). $M$. arenaria: protein carbonyls $=-0.0704 \times$ age $+1.472, r^{2}=0.24, N=23, P=0.005 ;$ L. elliptica: protein carbonyls $=0.052 \times$ age $+1.213, r^{2}=0.45, N=28, P<0.001$.

metabolic potential $\left(\mathrm{O}_{2}\right.$ consumed/g during the whole life span $=$ MSLP $\times$ SMR) was determined, a parameter comparable to the lifetime aerobic expenses calculated in the present study (Sohal et al., 1993). The longer lived Peromyscus leucopus showed a higher metabolic potential than the shorter lived Mus musculus, albeit both species showed similar SMRs. This indicates that other factors besides SMR crucially affect MLSP, e.g. antioxidant capacities.

\subsection{Do antioxidant defence capacities affect MLSP?}

In the present study, the long lived L. elliptica showed generally higher antioxidative capacities (catalase, glutathione) than the short lived $M$. arenaria. This is in line with a study by Estevez et al. (2002), who found higher tocopherol and carotene contents in the digestive gland of L. elliptica compared to M. arenaria. Sohal et al. (1993) also found higher antioxidant capacities in the longer lived rodent species, together with lower rates of mitochondrial ROS generation, which resulted in lower oxidative damage accumulation and were held responsible for the longer MLSP. In short-lived cephalopods with typically high standard metabolic rates, Zielinski and Pörtner (2000) found low levels of antioxidative defence which relate to the short MLSP of this group.

Distinct but opposite trends in glutathione concentration were found with age in L. elliptica and M. arenaria (Fig. 6). In L. elliptica glutathione decreased significantly with age, which is in line with several findings in humans, rats, insects and a marine bivalve (Sohal et al., 1987; Sanz et al., 1996; Canesi and Viarengo, 1997; Hernanz et al., 2000). Interestingly, despite lower glutathione concentrations at old age, the GSSG:GSH ratio remained constant throughout all ages in $L$. elliptica, reflecting unchanged tissue oxidation state. The clam might adjust the glutathione content to an age-related decrease in SMR, as it seems sufficient to keep the tissue oxidation stable in aged animals. A decrease in SMR with age was found in the mussel $M$. edulis (Sukhotin and Pörtner, 2001), but our data on L. elliptica did not allow for the analysis of this effect. It is unclear why tGSH concentration decreases, whereas catalase activity remains stable with age in L. elliptica as both destroy $\mathrm{H}_{2} \mathrm{O}_{2}$. The universal presence of glutathione in the mitochondrial matrix and different affinities of the involved enzymes, catalase (high $\mathrm{Km}$ ) and glutathione peroxidase (low $\mathrm{Km}$ ), for $\mathrm{H}_{2} \mathrm{O}_{2}$, may be responsible for the patterns observed (Chance et al., 1979; Phung et al., 1994; Schafer and Buettner, 2001; Rebrin et al., 2003; Barja, 2004). In $M$. arenaria, tGSH and the state of tissue oxidation increased significantly with age, indicating increased ROS scavenging in older animals. Leeuwenburgh et al. (1994) also reported an increase of $\mathrm{tGSH}$ with age in rat skeletal muscle along with increased levels of lipid oxidative damage markers, but tissue oxidation decreased in the rat skeletal muscle with age. Altogether it appears that the conservation of tissue redox state might be crucial to control the physiological ageing process which determines MLSP. A low GSSG:GSH ratio is important to ensure the availability of $\mathrm{GSH}$ in situations of oxidative stress and, moreover, GSSG accumulation stimulates protein S-glutathiolation that can cause irreversible loss of protein function (Klatt and Lamas, 2000).

In contrast to glutathione, antioxidant enzyme activities in $L$. elliptica and $M$. arenaria were independent of age, which implies a continuous need for a stable antioxidative protection system until old age. Data on age-related changes in antioxidative enzyme activities in other marine ectotherms (fish, crustaceans, worms, bivalves, cephalopods), however, show no conclusive pattern (Viarengo et al., 1989; Viarengo et al., 1991; Buchner et al., 1996; Mourente and Diaz-Salvago, 1999; Zielinski and Pörtner, 2000; Sukhotin et al., 2002; Correia et al., 2003; Passi et al., 2004). A thorough analysis of the response of enzymatic antioxidants to changes in physiological functions with age (metabolic rates, animal activity, body composition) may lead to a more detailed understanding of the role of various antioxidants in determining MLSP in aquatic ectotherms of different lifestyles and temperature regimes.

Lipofuscin content increased continuously with age in $L$. elliptica, as found in several other species (Leeuwenburgh et al., 1994; Zielinski and Pörtner, 2000; Bluhm et al., 2001; Sukhotin et al., 2002). A high share of unsaturated fatty acids in the membranes, a pattern frequently detected in low temperature fish, could facilitate lipid peroxidation, as they are more vulnerable to oxidative damage (Cossins et al., 1978; White and Somero, 1982). In L. elliptica, however, the level of total fatty acid unsaturation in soft tissue is similar to warm water bivalve species (Ahn et al., 2000). The comparison of two scallops, the Antarctic Adamussium 
colbecki and the temperate Pecten jacobaeus, resulted in a similar picture: Viarengo et al. (1995) found similar levels of unsaturated fatty acids, but distinctly higher levels of branched and short-chain saturated fatty acids in membranes of the digestive gland of $A$. colbecki. A high amount of unsaturated fatty acids would accelerate lipid peroxidation and therefore be adverse to a long MLSP, as it was found in air breathing mammals and birds, where higher unsaturated fatty acid contents in whole tissues and mitochondria are correlated with shorter life spans (Javouhey-Donzel et al., 1993; Pamplona et al., 1998; Herrero et al., 2001). The maintenance of low levels of unsaturated fatty acids as seen in L. elliptica might represent an antioxidant, presumably life-prolonging strategy. As age could be determined individually in L. elliptica, the relationship of physiological ageing parameters with age, and respectively with body mass, was explored (Table 2). $P$ values were highly significant for all parameters, except the GSSG:GSH ratio, irrespectively of whether plotting against age or mass, whereas $F$ values were always slightly higher for the parameter/age than the parameter/mass relationship, especially in the case of lipofuscin. This indicates a closer dependency of lipofuscin accumulation on age than on mass. In $M$. arenaria a distinction between age and body mass was unattainable as individual ages were calculated using a VBGM.

In contrast to findings in L. elliptica, lipofuscin content decreased in mantle tissue of $M$. arenaria with age during the first 5 years and increased thereafter (Fig. 7). A decrease from relatively high initial lipofuscin concentrations during early lifetime can be interpreted as a process of "rejuvenation" (Terman, 2001), associated with the dilution of waste material during intensive growth of the young. Such rejuvenation has also been found in $M$. edulis (Hole et al., 1995). The imbalance between higher metabolic rates of young $M$. arenaria causing high generation rates of reactive oxygen species and the constant antioxidant defence might cause the high lipofuscin content in young $M$. arenaria. Conversely, in specimens 5 years and older, a lower damage dilution due to slower growth and cell division may enhance lipofuscin particle density despite a decrease in SMR.

If not with unsaturated fatty acid levels, the increase in lipofuscin with age in L. elliptica may be related to soft tissue iron content. Iron is a transition metal, which propagates lipid radical formation. Estevez et al. (2002) found higher lipid radical formation in digestive gland homogenates of $L$. elliptica compared to $M$. arenaria going along with higher iron content in its tissues. Assuming that iron accumulates with age in L. elliptica soft body, this could enhance lipid radical formation and contribute to lipofuscin accumulation in older animals, as observed in human glia cells, cultured rat heart myocytes and marine ascomycetes (Thaw et al., 1984; Totaro et al., 1986; Marzabadi et al., 1988). Additionally, low temperature induces slow cell turnover rates, as documented for cold stenothermal Antarctic fishes compared to a eurythermal species (Brodeur et al., 2003). This may lead to sustained accumulation of oxidative damage products in the Antarctic L. elliptica. (Hirsch, 1978; Brunk and Terman, 2002). Nevertheless, absolute lipofuscin values at the same chronological age were always higher in $M$. arenaria compared to $L$. elliptica. In line with the more oxidized redox state (GSSG:GSH) this argues for age independent higher oxidative stress levels in $M$. arenaria, which may contribute to a reduced MLSP.

The marker for protein oxidation, protein carbonyl content, decreased significantly in $M$. arenaria but increased in L. elliptica with age (Fig. 8). As demonstrated in human fibroblasts (Sitte et al., 1998) protein carbonyls, in contrast to lipofuscin, can be readily degraded and thus effectively removed from the cells. Fast cell division, increasing tGSH content and continuously high protein degradation rates might prevent or even decrease carbonyl accumulation in $M$. arenaria with age. However, when excluding less than 4year-old bivalves from the analysis, the significant decrease in carbonyl content with age was abolished. Again, a slow down in growth and cell division in aging animals might lead to stable protein carbonyl contents in older individuals. Arbitrary grouping of the bivalves in different age groups is, however, statistically incorrect, and the above assumption should therefore be handled with care. Nevertheless, a slow down of protein carbonyl degradation or dilution with age would be in line with the enhanced lipofuscin accumulation found in $M$. arenaria individuals above 5 years of age.

In $L$. elliptica, the protein carbonyl content increased with age, which is in line with several vertebrate and invertebrate studies, reviewed by Sohal (2002). As tissue redox state (GSSG:GSH) remained constant with age in L. elliptica, the increase in carbonyl content seems to reflect progressive accumulation of oxidised proteins rather than an increase in

Table 2

Laternula elliptica: effects of age and body mass on physiological ageing parameters analysed with linear regression (ANOVA)

\begin{tabular}{|c|c|c|c|c|c|c|c|}
\hline $\begin{array}{l}\text { Physiological ageing } \\
\text { parameter }\end{array}$ & Vs. age $(F)$ & $P$ & Vs. body mass $(F)$ & $P$ & $N$ & Age range $(y)$ & $\begin{array}{l}\text { Mass range } \\
\text { (mg AFDM) }\end{array}$ \\
\hline Protein content & 35.5 & $<0.001$ & 25.76 & $<0.001$ & 31 & $4-36$ & $433-3062$ \\
\hline tGSH & 54.05 & $<0.001$ & 40.15 & $<0.001$ & 29 & $2-22$ & $100-2563$ \\
\hline GSSG & 22.91 & $<0.001$ & 18.59 & 0.002 & 28 & $2-22$ & $100-2563$ \\
\hline GSSG:GSH & 3.334 & 0.0809 & 2.677 & 0.1158 & 25 & $2-22$ & $100-2563$ \\
\hline Lipofuscin & 95.28 & $<0.001$ & 41.42 & $<0.001$ & 23 & $2.5-36$ & $135-3279$ \\
\hline Protein carbonyls & 21.64 & $<0.001$ & 17.25 & $<0.001$ & 28 & $4-28$ & $227-3506$ \\
\hline
\end{tabular}


protein oxidation rate with age. In fish and invertebrates in vivo protein synthesis rates are lower in Antarctic compared to temperate species at environmental temperature (Storch et al., 2003). Lower protein synthesis rates in L. elliptica compared to $M$. arenaria may therefore result in slower protein turnover leading to increased presence of more severely oxidised proteins. As extensively oxidised proteins become more resistant to proteolysis (Sitte et al., 1998; reviewed by Grune et al, 2004) this may lead to an accumulation of protein carbonyls with age, which may further be enhanced by a decrease of proteolytic activity with age, as shown in mammalian studies (Starke-Reed and Oliver, 1989; Grune et al., 2001). Additionally, according to Ahn et al. (2003), muscle proteins may be important energy reserves in $L$. elliptica, which enable the animals to survive prolonged periods of food-limitation in Antarctic waters. Consequently, a pronounced degradation of oxidised proteins might be avoided and protein oxidation tolerated in L. elliptica, to preserve protein energy stores. Additionally, lipofuscin accumulation in aged $L$. elliptica may exacerbate the impairment of protein degradation and storage of oxidized tissue protein, as shown by Sitte et al. (2000) for human fibroblasts cultures,

Along with the age-dependent increase in protein carbonyls in L. elliptica tissue, a decrease in protein content of mantle dry mass was found, whereas in $M$. arenaria the carbonyl content decreased and the protein content per mantle dry mass remained stable (Fig. 4). Age related loss of muscle proteins is well documented in humans and rats (Holloszy et al., 1991; Booth et al., 1994), and is presumably due to declining protein synthesis with age as shown for mitochondrial and mixed muscle protein in vertebrates (human, mouse) and invertebrates (Drosophila) (Marcus et al., 1982; Bailey and Webster, 1984; Welle et al., 1993; Rooyackers et al., 1996; Yarasheski, 2003). Declining protein synthesis rates with age and the use of proteins as energy source in L. elliptica might result in an imbalance of protein synthesis and protein usage in aged individuals, leading to a decrease in protein content with age. This may become problematic during prolonged periods of food limitation, in which survival of aged $L$. elliptica individuals may be hampered by the lack of energy reserves.

It remains unclear, to what extent and at which concentration lipofuscin and protein carbonyls impair cell functions. Terman (2001) proposed a lower degradation capacity of lipofuscin-loaded lysosomes, leading to an accumulation of damaged cell constituents, including mitochondria within the cell. This may exacerbate oxidative stress and compromise physiological function, including mitochondrial energy production. On the one hand our study does not confirm the "garbage theory of ageing" (Terman, 2001) as despite significant accumulation of lipofuscin and protein carbonyls with age, L. elliptica keeps tissue redox state in balance and grows three times older than $M$. arenaria. The $M$. arenaria data, on the other hand, corroborate this hypothesis by showing generally higher levels of lipofuscin contents and tissue oxidation at all ages compared to L. elliptica, which could indicate more damaged and therefore ROS generating mitochondria in $M$. arenaria tissue. Further studies are required to understand the influence of oxidative damage on the change in physiological functions with age in marine mud clams.

\section{Conclusions}

The long-lived polar L. elliptica showed lower SMR than the shorter lived temperate $M$. arenaria, but higher lifetime aerobic turnover at maximum age. This may indicate that the MLSP may depend more on the average rate of respiration than on the magnitude of lifetime aerobic energy turnover. Furthermore, higher antioxidant capacities and a more reduced tissue oxidation state throughout life seem to lead to the observed higher MLSP in the polar mud clam. An increase of oxidative damage parameters with age in $L$. elliptica does obviously not accelerate the physiological ageing process, as the species eventually lives three times longer than $M$. arenaria. The lower metabolic rates and maintenance of a low tissue redox state found in $L$. elliptica compared to $M$. arenaria may enable the polar species to reach a higher MLSP. We are currently undertaking measurements of the changes of mitochondrial functions with age in both species, to further elucidate the different ageing patterns found in this study.

\section{Acknowledgements}

Rob Dekker and the Crew from the RV Navicula from the NIOZ kindly took E. Philipp on several sampling trips to collect $M$. arenaria. Many thanks to the Argentinean Divers, the Station Management of Jubany, to Olaf Heilmayer, Kerstin Beyer and Frank Becker for logistic as well as scientific support at the Argentinean Antarctic Base Jubany and in Bremerhaven. The study was supported by a student grant of the University of Bremen.

\section{References}

Aebi, H., 1984. Catalase in vitro. Methods Enzymol, 105, 121-126. Ahn, I.Y., Cho, K.W., Choi, K.S., Seo, Y., Shin, J., 2000. Lipid content and composition of the Antarctic lamellibranch, Laternula elliptica (King \& Broderip) (Anomalodesmata: Laternulidea), in King George Island during an austral summer. Pol. Biol. 23, 24-33.

Ahn, I.Y., Shim, J.H., 1998. Summer metabolism of the Antarctic clam, Latemula elliptica (King and Broderip) in Maxwell Bay, King George Island and its implications. J. Exp. Mar. Biol. Ecol. 224, 253264.

Ahn, I.Y., Surh, J., Park, Y.G., Kwon, H., Choi, S.K., Kang, S.H., Choi, J.H., Kim, K.W., Chung, H., 2003. Growth and seasonal energetics of the Antarctic bivalve Laternula ellipticafrom King George Island, Antarctica. Mar. Ecol. Prog. Ser. 257, 99-110. 
Bailey, P.J., Webster, G.C., 1984. Lowered rates of protein synthesis by mitochondria isolated from organisms of increasing age. Mech. Ageing Dev. 24, 233-241

Barja, G., 2004. Aging in vertebrates, and the effect of caloric restriction: a mitochondrial free radical production-DNA damage mechanism? Biol. Rev. Camb. Philos. Soc. 79, 235-251.

Benson, B.B., Krause, D.J., 1984. The concentration and isotopic fractionation of oxygen dissolved in freshwater and seawater in equilibrium with the atmosphere. Limnol. Oceanogr. 29 (3), 620-632.

Bluhm, B.A., Brey, T., Klages, M., 2001. The autofluorescent age pigment lipofuscin: key to age, growth and productivity of the Antarctic amphipod Waldeckia obesa (Chevreux, 1905). J. Exp. Mar. Biol. Ecol. 258, 215-235.

Booth, F.W., Weeden, S.H., Tseng, B.S., 1994. Effect of aging on human skeletal muscle and motor function. Med. Sci. Sports Exerc. 26, $556-560$.

Brey, T., 1991. Population dynamics of Sterechinus antarcticus (Echinodermata: Echinoidea) on the Weddell Sea shelf and slope, Antarctica. Ant. Sci. 3 (3), 251-256.

Brey, T., Mackensen, A., 1997. Stable isotopes prove shell growth bands in the Antarctic bivalve Laternula elliptica to be formed annually. Pol. Biol. 17, 465-468.

Brey, T., Pearse, J., Basch, L., MCCintock, J., Slattery, M., 1995. Growth and production of Sterechinus neumayeri (Echinoidae: Echinodermata) in McMurdo Sound, Antarctica. Mar. Biol. 124, 279-292.

Brodeur, J.C., Calvo, J., Clarke, A., Johnston, I.A., 2003. Myogenic cell cycle duration in Harpagifer species with sub-Antarctic and Antarctic distributions: evidence for cold compensation. J. Exp. Biol. 206, 10111016.

Brousseau, D.J., Baglivo, J.A., 1987. A comparative study of age and growth in Mya arenaria (soft-shell clam) from three populations in Long Island Sound. J. Shellifsh Res. 6, 17-24.

Brunk, U.T., Terman, A., 2002. The mitochondrial-lysosomal axis theory of aging: accumulation of damaged mitochondria as a result of imperfect autophagocytosis. Eur. J. Biochem. 269, 1996-2002.

Buchner, T., Abele-Oeschger, D., Theede, H., 1996. Aspects of antioxidant status in the Polychaete Arenicola Marina: tissue and subcellular distribution, and reaction to environmental hydrogen peroxide and elevated temperatures. Mar. Ecol. Prog. Ser. 143, 141-150.

Cailliet, G.M., Andrews, A.H., Burton, E.J., Watters, D.L., Kline, D.E., Ferry-Graham, L.A., 2001. Age determination and validation studies of marine fishes: do deep-dwellers live longer? Exp. Gerontol. 36, 739-764.

Canesi, L,, Viarengo, A., 1997. Age-related differences in glutathione metabolism in Mussel tissues (Mytilus edulis L.). Comp. Biochem. Phys. B 116, 217-221.

Chance, B., Sies, H., Boveris, A., 1979. Hydroperoxide metabolism in mammalian organs. Physiol. Rev. 59, 527-605.

Clarke, A., 1983. Life in cold water: the physiological ecology of polar marine ectothermes. Oceanogr. Mar. Biol. Ann. Rev. 341-453.

Clarke, A., 1988. Seasonality in the antarctic marine environment. Comp. Biochem. Phys. B 90B, 461-473.

Clarke, A., 1991. Cold adaptation. J. Zool. 225, 691-699.

Correia, A.D., Costa, M.H., Luis, O.J., Livingstone, D.R., 2003. Age-related changes in antioxidant enzyme activities, fatty acid composition and lipid peroxidation in whole body Gammarus locusta (Crustacea: Amphipoda). J. Exp. Mar. Biol. Ecol. 289, 83-101.

Cossins, A.R., Christiansen, J., Prosser, C.L., 1978. Adaptation of biological membranes to temperature. The lack of homeoviscous adaptation in the sarcoplasmic reticulum. Biochim. Biophys. Acta 511, 442454.

Estevez, S.M., Abele, D., Puntarulo, S., 2002. Lipid radical generation in polar (Laternula elliptica) and temperate (Mya arenaria) bivalves. Comp. Biochem. Phys. B 132, 729-737.

Fariss, M.W., Reed, D.J., 1987. High-performance liquid chromatography of thiols and disulfides: dinitrophenol derivatives. Methods Enzymol. $143,101-109$.
Gatti, S., Brey, T., Müller, W.E.G., Heilmayer, O., Holst, G., 2002. Oxygen microoptodes: a new tool for oxygen measurements in aquatic animal ecology. Mar. Biol. 140, 1075-1085.

Grune, T., Shringarpure, R., Sitte, N., Davies, K., 2001. Age-related changes in protein oxidation and proteolysis in mammalian cells. J. Gerontol. A Biol. Sci. Med. Sci. 56, B459-B467.

Grune, T., Jung, T., Merker, K., Davies, K.J.A., 2004. Decreased proteolysis caused by protein aggregates, inclusion bodies, plaques, lipofuscin, ceroid, and 'aggresomes' during oxidative stress, aging, and disease. Int. J. Biochem. Cell Biol. 36, 2519-2530.

Harman, D., 1956. Aging: a theory based on free radical and radiation biology. J. Gerontol. 11, 298-300.

Heilmayer, O., Brey, T., 2003a. Saving by freezing? Metabolic rates of Adamussium colbecki in a latitudinal context. Mar. Biol. 143 (3), 477-484.

Heilmayer, O., Brey, T., Chiantore, M., Cattaneo-Vietti, R., Arntz, W.E., 2003b. Age and productivity of the Antarctic scallop, Adamussium colbecki, in Terra Nova Bay (Ross Sea, Antarctica). J. Exp. Mar. Biol. Ecol. 288, 239-256

Heilmayer, O., Brey, T., Storch, D., Mackensen, A., Arntz, W.E., 2004. Population dynamics and metabolism of Aequipecten opercularis (L.) from the western English Channel (Roscoff, France). J. Sea Res. 52, $33-44$.

Hernanz, A., Fernandez-Vivancos, E., Montiel, C., Vazquez, J.J., Arnalich, F., 2000. Changes in the intracellular homocysteine and glutathione content associated with aging. Life Sci. 67, 1317-1324.

Herrero, A., Portero-Otin, M., Josep Bellmunt, M., Pamplona, R., Barja, G. 2001. Effect of the degree of fatty acid unsaturation of rat heart mitochondria on their rates of $\mathrm{H}_{2} \mathrm{O}_{2}$ production and lipid and protein oxidative damage. Mech. Ageing Dev. 122, 427-443.

Hill, K.T., Womersley, C., 1991. Critical aspects of fluorescent age-pigment methologies: modification for accurate analysis and age assessments in aquatic organisms. Mar. Biol. 109, 1-11.

Hirsch, H.R., 1978. The waste-product theory of aging: waste dilution by cell division. Mech. Ageing Dev, 8, 51-62.

Hole, L.M., Moore, M.N., Bellamy, D., 1995. Age-related cellular and physiological reactions to hypoxia and hyperthermia in marine mussels. Mar. Ecol. Prog. Ser. 122, 173-178.

Holloszy, J.O., Chen, M., Cartee, G.D., Young, J.C., 1991. Skeletal muscle atrophy in old rats: differential changes in the three fiber types. Mech. Ageing Dev. 60, 199-213.

Javouhey-Donzel, A., Guenot, L., Maupoil, V., Rochette, L., Rocquelin, G. 1993. Rat vitamin $E$ status and heart lipid peroxidation: effect of dietary alpha-linolenic acid and marine n-3 fatty acids. Lipids $28,651-655$.

Jonkers, H.A., 1999. Aligned growth positions in Pliocene Laternula elliptica (King \& Broderip) (Bivalvia: Anomalodesmata: Laternulidae). Ant. Sci. 11, 463-464.

Klatt, P., Lamas, S., 2000. Regulation of protein function by S-glutathiolation in response to oxidative and nitrosative stress. Eur. J. Biochem. 267, $4928-4944$

Krantz, D.E., Jones, D.S., Williams, D.F., 1984. Growth rates of the sea scallop, Placopecten magellanicus, determined from the super(18)O/ super(16)O record in shell calcite. Biol. Bull. Mar. Biol. Lab. Woods Hole 167 (1) , 186-199.

Kresze, G.-B., 1988. Methods for protein determination. In: Bergmeyer, H.U. (Ed.), Methods of Enzymatic Analysis.. VCH, Weinheim, pp. 8488

La Mesa, M., Vacchi, M., 2001. Review. Age and growth of high Antarctic notothenioid fish. Ant. Sci. 13, 227-235.

Leeuwenburgh, C., Fiebig, R., Chandwaney, R., Ji, L.L., 1994. Aging and exercise training in skeletal muscle: responses of glutathione and antioxidant enzyme systems. Am. J. Physiol. Reg. 1267, R439-R445.

Levine, R.L., Garland, D., Oliver, C.N., Amici, A., Climent, I., Lenz, A.-G., Ahn, B.-W., Shaltiel, S., Stadtman, E.R., 1990. Determination of carbonyl content in oxidatively modified proteins. Methods Enzymol. $186,464-478$ 
Livingstone, D.R., Lips, F., Garcia Martinez, P., Pipe, R.K., 1992. Antioxidant enzymes in the digestive gland of the common mussel Mytilus edulis. Mar. Biol. 112, 265-276.

MacDonald, B.A., Thomas, M.L.H., 1980. Age determination of the soft shell clam Mya arenaria using shell internal growth lines. Mar. Biol. 58, 105-109.

Marcus, D.L., Ibrahim, N.G., Freedman, M.L., 1982. Age-related decline in the biosynthesis of mitochondrial inner membrane proteins. Exp. Gerontol. 17, 333-341.

Martinez, D.E., 1998. Mortality patterns suggest lack of senescence in Hydra. Exp. Gerontol. 33, 217-225.

Marzabadi, M.R., Sohal, R.S., Brunk, U.T., 1988. Effect of ferric iron and desferrioxamine on lipofuscin accumulation in cultured rat heart myocytes. Mech. Ageing Dev. 46, 145-157.

Mourente, G., Diaz-Salvago, E., 1999. Characterization of antioxidant systems, oxidation status and lipids in brain of wild-caught size-class distributed Aristeus antennatus (Risso, 1816) Crustacea, Decapoda. Comp. Biochem. Phys. B 124, 405-416.

Pamplona, R., Portero-Otin, M., Riba, D., Ruiz, C., Prat, J., Bellmunt, M.J., Barja, G., 1998. Mitochondrial membrane peroxidizability index is inversely related to maximum life span in mammals. J. Lipid Res. 39, 1989-1994.

Passi, S., Ricci, R., Cataudella, S., Ferrante, I., De Simone, F., Rastrelli, L., 2004. Fatty acid pattern, oxidation product development, and antioxidant loss in muscle tissue of rainbow trout and Dicentrarchus labrax during growth. J. Agric. Food Chem. 52, 2587-2592.

Pearl, R., 1928. The Rate of Living. Alfred Knopf, New York.

Petersen, K.S., Rasmussen, K.L., Heinemeler, J., Rud, N., 1992. Clams before Columbus? Nature 359, 679.

Phung, C.D., Ezieme, J.A., Turrens, J.F., 1994. Hydrogen peroxide metabolism in skeletal muscle mitochondria. Arch. Biochem. Biophys. 315, $479-482$.

Rebrin, I., Kamzalov, S., Sohal, R.S., 2003. Effects of age and caloric restriction on glutathione redox state in mice. Free Radic. Biol. Med. 35, 626-635.

Rooyackers, O.E., Adey, D.B., Ades, P.A., Nair, K.S., 1996. Effect of age on in vivo rates of mitochondrial protein synthesis in human skeletal muscle. Proc. Natl. Acad. Sci. U.S.A. 93, 15364-15369

Sanz, N., Diez-Fernandez, C., Cascales, M., 1996. Variations of hepatic antioxidant systems and DNA ploidy in rats aged 2 to 8 months. Biochim. Biophys. Acta 1315, 123-130.

Schafer, F.Q., Buettner, G.R., 2001. Redox environment of the cell as viewed through the redox state of the glutathione disulfide/glutathione couple. Free Radic. Biol. Med. 30, 1191-1212.

Sitte, N., Huber, M., Grune, T,, Ladhoff, A., Doecke, W.D., Von Zglinicki, T., Davies, K.J., 2000. Proteasome inhibition by lipofuscin/ceroid during postmitotic aging of fibroblasts. Faseb J. 14, 1490-1498.

Sitte, N., Merker, K., Grune, T., 1998. Proteasome-dependent degradation of oxidized proteins in MRC-5 fibroblasts. FEBS Lett. 440, 399-402.

Sohal, R.S., 1986. The rate of living theory: a contemporary interpretation, in: Collantz, K.G., S.R. (Ed.). Insect Aging. Springer-Verlag, Berlin, pp. $23-44$.

Sohal, R.S., 2002. Role of oxidative stress and protein oxidation in the aging process. Free Radic. Biol. Med. 33, 37-44.

Sohal, R.S., Ku, H.H., Agarwal, S., 1993. Biochemical correlates of longevity in two closely related rodent species. Biochem. Biophys. Res. Commun. 196, 7-11.

Sohal, R.S., Toy, P.L., Farmer, K.J., 1987. Age-related changes in the redox status of the housefly, Musca domestica. Arch. Gerontol. Geriatr. 6, 95-100.
Soot-Ryen, T., 1952. Laternula elliptica (King \& Broderip 1831) from the Pecten-conglomerate, Cockburn Islan. Arkiv för Zoologi 4, 163-164.

Starke-Reed, P.E., Oliver, C.N., 1989. Protein oxidation and proteolysis during aging and oxidative stress. Arch. Biochem. Biophys. 275, 559-567.

Storch, D., Heilmayer, O., Hardewig, I., Portner, H.O., 2003. In vitro protein synthesis capacities in a cold stenothermal and a temperate eurythermal pectinid. J. Comp. Physiol. B 173, 611-620.

Strasser, M., 1999. Mya arenaria- an ancient invader of the North Sea coast. Helgoländer Meeresuntersuchungen 52, 309-324.

Sukhotin, A.A., Abele, D., Pörtner, H.O., 2002. Growth, metabolism and lipid peroxidation in Mytilus edulis: age and size effects. Mar. Ecol. Prog. Ser. 226, 223-234.

Sukhotin, A.A., Pörtner, H.-O., 2001. Age-dependence of metabolism in mussels Mytilus edulis (L.) from the White Sea. J. Exp. Mar. Biol. Ecol. $257,53-72$.

Terman, A., 2001. Garbage catastrophe theory of aging: imperfect removal of oxidative damage? Redox Rep. 6, 15-26.

Thaw, H.H., Collins, V.P., Brunk, U.T., 1984. Influence of oxygen tension, pro-oxidants and antioxidants on the formation of lipid peroxidation products (lipofuscin) in individual cultivated human glial cells. Mech. Ageing Dev. 24, 211-223.

Totaro, E., Cuomo, V., Pisanti, F.A., 1986. Infuence of environmental stress on lipofuscin production. Arch. Gerontol. Geriatr. 5, 343-349.

Vernet, M., Hunter, J.R., Vetter, R.D., 1988. Accumulation of age-pigments (lipofuscin) in two cold-water fishes. Fish Bull. 86, 401-407.

Viatengo, A., Canesi, L., Martinez, P.G., Peters, L.D., Livingstone, D.R., 1995. Pro-oxidant processes and antioxidant defence systems in the tissues of the Antarctic scallop (Adamussium colbecki) compared with the Mediterranean scallop (Pecten jacobaeus). Comp. Biochem. Phys. B $111,119-126$

Viarengo, A., Canesi, L., Pertica, M., Livingstone, D.R., Orunesu, M., 1991. Age-related lipid peroxidation in the digestive gland of mussels: the role of antioxidant defence systems. Experientia 47, 454-457.

Viarengo, A., Pertica, M., Canesi, L., Accomando, R., Mancinelli, G., Orunesu, M., 1989. Lipid peroxidation and level of antioxidant compounds (GSH, vitamin E) in the digestive glands of mussels of three different age groups exposed to anaerobic and aerobic conditions. Mar. Environ. Res. 28, 291-295.

Von Bertalanffy, L., 1934. Untersuchungen über die Gesetzlichkeit des Wachstums. Arch.f.Entwicklungsmechanik d.Organismen 131, 613652 .

Wefer, G., Berger, W.H., 1991. Isotope paleontology; growth and composition of extant calcareous species. Mar. Geo. 100, 207-248.

Welle, S., Thornton, C., Jozefowicz, R., Statt, M., 1993. Myofibrillar protein synthesis in young and old men. Am. J. Physiol. 264, E693-E698.

White, F.N., Somero, G.N., 1982. Acid-base-regulation and phospholipid adaptations to temperature; time sources and physiological significance of modifying in the milieu for protein function. Physiol. Rev. 62 (1), 40-90.

Yarasheski, K.E., 2003. Exercise, aging, and muscle protein metabolism. J. Gerontol. A Biol. Sci. Med. Sci. 58, M918-M922.

Zielinski, S., Pörtner, H.O., 2000. Oxidative stress and antioxidative defense in cephalopods: a function of metabolic rate or age? Comp. Biochem. Phys. B 125, 147-160.

Ziuganov, V., Miguel, E.S., Neves, R.J., Longa, A., Fernandez, C., Amaro, R., Beletsky, V., Popkovitch, E., Kaliuzhin, S., Johnson, T., 2000. Life span variation of the freshwater pearl shell: a model species for testing longevity mechanisns in animals. AMBIO: J. Hum. Environ. 29, 102-105. 